\title{
The Effects of an Interactive, Computer-Based, Abstinence Education Curriculum on Selected Student Outcomes
}

\author{
Kathy DiFiore ${ }^{1}$, Vincent Mays ${ }^{2}$, Sharon Ross ${ }^{1}$ \\ ${ }^{1}$ Several Sources Foundation \\ ${ }^{2}$ Newark Public Schools
}

\begin{abstract}
The purpose of this study was to examine the effects of The Choice Game ${ }^{\mathrm{TM}}$, an abstinence-untilmarriage education program, on the knowledge, attitudes, and behavioral intent on sexual behavior. The sample for this study consisted of 959 students (537 treatment, 422 control) from 17 public and parochial schools located in urban areas of Northern New Jersey. The curriculum was implemented in regularly scheduled health education classes by trained instructors. Students in both the treatment and control groups voluntarily completed a questionnaire before and after curriculum implementation in their regular classroom setting. To assess the impact of the program, pre- post-gain scores for each scale were computed, and then compared by group (treatment or control) using an independent samples t test. All five student outcomes (Knowledge, Family Communication, Attitude Toward Abstinence, Behavioral Intent, and Abstinence Until Marriage) showed significantly $(\mathrm{p}<.01)$ greater gains for the treatment group than for the control group.
\end{abstract}

(C) 2007 Californian Journal of Health Promotion. All rights reserved. Keywords: Abstinence, urban schools, technology, minority students

The history of sex education in the United States has been a history filled with controversy (Irvine, 2002). That controversy continues today in the debate over whether abstinence until marriage education, or a more comprehensive approach to sexuality education, is in the best interest of our nation's young people. The current administration has chosen to promote an abstinence until marriage approach. Young \& Penhollow (2006) have noted that while it might be "tempting to say abstinence programs are simply not effective in helping young people postpone sexual involvement or avoid risky sexual behavior" such a statement is not an accurate reflection of the research literature. These authors indicated that there was limited evidence of the effectiveness of abstinence education programs, pointed out that the vast majority of abstinence education programs had not been evaluated, and encouraged researchers to become involved in examining the impact of abstinence education programs on student outcomes.
Consistent with the recommendations of Young \& Penhollow (2006), this study examined the impact of an abstinence education on selected student outcomes. Specifically, the purpose of the study was to examine the effects of The Choice Game ${ }^{\mathrm{TM}}$, an abstinence until marriage education program, on the knowledge, attitudes and intent of selected public and parochial students from an urban school district in northern New Jersey, relative to sexual behavior.

\section{Methods}

\section{Intervention}

The intervention in this study was The Choice Game ${ }^{\mathrm{TM}}$, an interactive computer-based, abstinence education curriculum. The Choice Game curriculum is based on Bandura's social cognitive learning theory (Bandura renamed the theory Social Cognitive Theory), which posits that behavior is shaped not only by its consequences for the individual but also through modeling, in which behavior is affected by the consequences the individual observes occurring to another. Social cognitive learning theory 
hypothesizes that the observer will be more influenced by a model given three conditions: (1) if the model is colorful and dramatic, (2) if the model is attractive, or prestigious, or appears to be particularly competent, and (3) if the model seems more like the observer (Bandura, 1997).

The Choice Game ${ }^{\mathrm{TM}}$ provides simulated real-life situations exploring various topics, such as dating, premarital sex, peer pressure, drugs and alcohol, teen pregnancy, and STDs for students to explore and navigate. Students are given opportunities to choose options that lead them on varying paths. Real actors play the characters in film clips with each film clip lasting an average of one minute. The alternative endings and the multi-cultural cast give the students real life experiences that help them to relate what they are learning to their daily challenges. In each lesson, students are introduced to the topic through a clip from the CD-ROM or DVD. From this first clip, students can make decisions about what they might do in the situation. After selecting their decision, another scenario is played, at the end of which, another decision can be made. As students make a decision in "real time", they are able to view its consequences. Student and parent journals are also provided so that students can reflect on what was discussed each session and parents can understand the material that their child has been learning through The Choice Game.

\section{Participants}

The sample for this study consisted of (537 treatment, 422 control) students from eight public and nine parochial schools located in urban areas of Northern New Jersey. All schools were selected based on agreement to participate in this study with random assignment to either treatment (13 schools) or control (four schools) groups. In each school, classrooms were identified that served as intervention classrooms (at intervention schools) or comparison classrooms (at control schools). Parental consent forms were sent home to each student participating in the study, and these forms were signed if parents were not interested or willing to have their child participate in the program. Since no forms were returned indicating an unwillingness to have their child participate (passive consent), all students participated in this program.

\section{Instrument}

The instrument was a self-report, Likert-like questionnaire that included five scales: Knowledge (six items, alpha $=.46$ ), Family Communication (five items, alpha $=.69$ ), Attitude Toward Abstinence (three items, alpha $=.24$ ), Behavioral Intent (eight items, alpha = .61), and Abstinence Until Marriage (one item). Psychometric data for the scale items are in Appendix A. The last "scale" was a single item, worded "I plan to be sexually abstinent (not have sex) until marriage." It was part of the behavioral intent measure, but was also considered separately as an outcome because it is a central focus of the program. The response options were Yes, No, Not Sure or True, False, Not Sure. Internal consistency measures for the five scales were based on pretest data from the study sample and were computed using Cronbach’s alpha.

\section{Curriculum Implementation}

The curriculum was implemented in regularly scheduled health education classes by trained instructors. These instructors had received a minimum of fifty hours of training provided by the developers of The Choice Game. The curriculum consists of six core lessons, each 45minutes in length, which include the topics "My Family, My Self”; "Influences"; "Communication \& Refusal Skills"; "STDs \& AIDS"; "Alcohol, Drugs, Tobacco Use"; and "Teen Pregnancy." The remaining sessions of the curriculum included time for pre- and postevaluation as well as one graduation and awards session. Students received this material one day per week during their health education class period.

The instructors each presented the material via a laptop computer and a projector. Students viewed the opening scene from each lesson, the instructor then presented an educational segment and divided students into smaller groups to play and discuss the game in real time. After completion of each of the lessons, students were instructed to complete lesson related activities 
from the student journal. Students were also given an audio CD and game CDs each week to share with family and friends to reinforce curriculum messages, and to assist in the completion of journal assignments. The audio nature of the take-home material allowed parents with low literacy an opportunity to be involved in the abstinence education activities.

Students in the treatment group received The Choice Game one day a week. Students in the control group received standard health education information which reflected the New Jersey Core Curriculum Content Standards (New Jersey Department of Education, 2004).

\section{Procedure}

Students in both the treatment and control groups voluntarily completed the questionnaire before and after curriculum implementation in their regular classroom setting. Students were each assigned a unique identification number which allowed student responses to be matched over time. To assess the impact of the program, pre- and post-gain scores for each scale were computed. An independent samples t test was used to compare the treatment and control group scores.

\section{Results}

\section{Sample Demographics}

The project involved student participants from 17 schools. Across all schools, 959 students had a matching ID number at pretest and posttest. This sample was comprised of $52.5 \%$ females (T: 55.7\%, C: $49.2 \%$ ) and $47.5 \%$ males ( $\mathrm{T}$ : $44.3 \%$, C: $50.8 \%$ ). The majority of the students described themselves as "Black or AfricanAmerican" (67.8\%; T: 66.7\%, C: 69.2\%) or "Hispanic or Latino" (18.4\%; T: 17.4\%, C: 13.5\%). The sample also included White, Asian, Pacific Islander, American Indian, and Arabic students $(14.7 \%)$. The students ranged in age from 12 to 18 . The majority of the students were 14 (53\%) and 15 (31.2\%). Schools varied considerably in their percentages of students with matching pretest and posttest scores, ranging from zero percent at one public school that did not administer the posttest, to $100 \%$ at one of the parochial schools.

\section{Outcome Gains by Group}

To assess the effectiveness of the program, prepost gains were computed, and means were compared via an independent samples $t$ test where the independent variable was Group (treatment or control) (see Table 1).

Table 1

Pre- and post-gain differences by treatment and school type ( $\mathrm{N}=959)$

\begin{tabular}{|c|c|c|c|c|c|}
\hline Subscale Gains by Group & N & \multicolumn{1}{c|}{ Mean+SD } & t & Sig. & d \\
\hline Knowledge Percent Gain & & & $t(954)=9.50$ & $<.01$ & .59 \\
\hline The Choice Game & 536 & $15.09 \pm 25.74$ & & & \\
\hline Control & 420 & $-0.52 \pm 24.51$ & & & \\
\hline Family Communication Gain & & & $t(957)=2.81$ & $<.01$ & .18 \\
\hline The Choice Game & 537 & $0.11 \pm 0.50$ & & & \\
\hline Control & 422 & $0.02 \pm 0.49$ & & & \\
\hline Attitude Toward Abstinence Gain & & & $t(956)=5.11$ & $<.01$ & .33 \\
\hline The Choice Game & 536 & $0.18 \pm 0.50$ & & & \\
\hline Control & 422 & $0.01 \pm 0.52$ & & & \\
\hline Behavioral Intent Gain & & & $t(956)=6.58$ & $<.01$ & .42 \\
\hline The Choice Game & 536 & $0.12 \pm 0.34$ & & & \\
\hline Control & 422 & $-0.02 \pm 0.34$ & & & \\
\hline Abstinence Until Marriage Gain & & & $t(955)=6.80$ & $<.01$ & .43 \\
\hline The Choice Game & 535 & $0.30 \pm 0.79$ & & & \\
\hline Control & 421 & $-0.03 \pm 0.71$ & & & \\
\hline
\end{tabular}


All five student outcomes (Knowledge, Family Communication, Attitude Toward Abstinence, Behavioral Intent, and Abstinence Until Marriage) showed significantly $(\mathrm{p}<.01)$ greater gains for the treatment group than for the comparison group. Effect sizes ranged from .18 standard deviations for the family communication measure to .59 standard deviations for the Knowledge measure. For the Behavioral Intent and Abstinence Until Marriage measures, the effect sizes were .42 and .43, respectively. These effect sizes mean that a student at the 50th percentile will, on average, move to the 66th and 67th percentiles after the program on these outcomes.

\section{Discussion}

Studies of abstinence-only education programs have demonstrated varying results. One of the largest abstinence-only program evaluations involved the testing of Postponing Sexual Involvement (PSI) (Kirby, Korpi, Barth, \& Cagampang, 1997) PSI demonstrated no significant difference in pre- and postintervention self-reported scores on the initiation of sex, frequency of sex, number of sex partners, use of condoms or reported pregnancy rates. Although studies have shown that some abstinence programs have produced positive effects (Denny \& Young, 2006; Denny, Young, Rausch \& Spear 2002; Denny, Young \& Spear 1999; Goldfarb, Donnelly, Duncan, et al.,1999; Jorgensen, 1991; Jorgensen, Potts \& Camp, 1993; Lerner, 2005; St Pierre, Mark, Kaltreider, et al.,1995; Young, Core-Gebhart \& Marx, 1992), even the positive evaluations do have problems relative to research design (lack of random assignment, inadequate follow-up, or attrition over time) which limit the strength of the findings.

As demonstrated through the findings of this study, The Choice Game curriculum produced significant gains in the treatment group in
Knowledge, Family Communication, Attitude Toward Abstinence, Behavioral Intent, and Abstinence Until Marriage. These findings may not necessarily translate into a reduction in risky sexual behavior, but nevertheless, they are encouraging.

There are many abstinence education programs that are currently available. Relatively few of these programs have been evaluated. Of those that have been evaluated and published, the majority have used relatively weak evaluation designs (Denny \& Young, 2006; Kirby, 2001; Young \& Penhollow, 2006). In the present study, the use of randomly assigned treatment and control groups and the matching of student scores from pretest to posttest increase the confidence that changes over time were directly attributable to the curriculum intervention.

Limitations of this study included the inability to collect behavioral data and lack of follow-up data. Thus, findings do not reflect actual sexual behaviors of students or the effect of the abstinence education program on sexual behavior outcomes. Future research must include measures of actual behavior. Additionally, the effects that were produced were immediate program effects. Future research must follow both intervention and control students for an extended period of time.

One of the greatest challenges that any educational/ behavioral change program faces is reaching a large and diverse population of students. This study population included a large percentage of minority students and students from both public and parochial schools. This enhances the external validity of the findings. These results are promising for the future of abstinence education and demonstrate that a technology driven abstinence education program can produce positive student outcomes.

\section{References}

Bandura, A. (1997). Social learning theory. New York: General Learning Press.

Denny, G., \& Young, M. (2006). An evaluation of an abstinence only sex education curriculum: An 18 month follow-up. Journal of School Health, 76, 414-422. 
Denny, G., Young, M., Rausch, S. \& Spear, C. (2002). An evaluation of an abstinence education curriculum series: Sex can wait. American Journal of Health Behavior, 26, 366-377.

Denny G, Young, M., \& Spear, C. (1999). An evaluation of the "sex can wait" abstinence education curriculum series. American Journal of Health Behavior, 23, 134-143.

Goldfarb, E. S., Donnelly, J., Duncan, D. F. et al. (1999). Evaluation of an abstinence-based curriculum for early adolescents: First year changes in sex attitudes, knowledge and behavior. North American Journal of Psychology, 1, 243-254.

Irvine, J. M. (2002). Talk about sex: The battles over sex education in the United States. Berkeley CA: The University of California Press.

Jorgensen, S. R. (1991). Project taking charge: An evaluation of an adolescent pregnancy prevention program Family Relations, 40, 373-380.

Jorgensen, S. R., Potts, V., \& Camp, B. (1993). Project taking charge: Six-month follow-up of a pregnancy prevention program for early adolescents Family Relations, 42, 401-406.

Kirby, D. (2001). Emerging answers: Research findings on programs to reduce teen pregnancy. Washington D.C.: The National Campaign to Prevent Teen Pregnancy.

Kirby, D., Korpi, M., Barth, R. P., \& Cagampang, H. H. (1997). The impact of the postponing sexual involvement curriculum among youths in California. Family Planning Perspectives, 29(3), 100108.

Lerner, R. (2005). Can abstinence work: An analysis of the "best friends” program. Adolescent and Family Health, 3(4), 185-192.

New Jersey Department of Education, Division of Educational Programs and Assessment (2004). New Jersey Core Curriculum Content Standards. Retrieved March 27, 2007, from http://www.nj.gov/njded/cccs/cccs.pdf

St. Pierre, T. L., Mark, M. M., Kaltreider, D. L. et al. (1995). A 27-month evaluation of a sexual activity prevention program in boys and girls clubs across the nation. Family Relations, 44, 69-77.

Young, M., Core-Gebhart, P. \& Marx, D. (1992). Abstinence-oriented sexuality education: Initial field test results of the Living Smart curriculum. Family Life Educator, 10(summer), 4-8.

Young, M., \& Penhollow, T. (2006). The impact of abstinence education: What does the research say? American Journal of Health Education, 37, 194.

\section{Acknowledgements}

This research was supported in part by a grant to Several Sources Foundation from the United States Department of Health and Human Services / Maternal and Child Health Bureau Special Projects of Regional and National Significance (SPRANS) Community-Based Abstinence Education Program (CFDA \#93.110). The authors wish to express their gratitude to the Newark School District for their cooperation in the conduct of this study.

Author Information

Kathy DiFiore, M.B.A.*

Several Sources Foundation

300 Airmount Avenue

Ramsey, NJ 07446

Ph.: 201-825-7277

Vincent Mays, Ph.D.

Newark Public Schools

Pathways Academy

398-400 Hawthorne Avenue

Newark, NJ 07105

Ph.: 973-351-2029 
Sharon Ross

Several Sources Foundation

300 Airmount Avenue

Ramsey, NJ 07446

Phone: (201) 825-7277

* corresponding author 


\section{Appendix A \\ Psychometric Data for Scale Items}

\begin{tabular}{|c|c|c|c|}
\hline Scale and Items & Mean & SD & $\begin{array}{c}\text { corrected } \\
\text { item-total } \\
\text { correlation }\end{array}$ \\
\hline \multicolumn{4}{|l|}{$\begin{array}{l}\text { Knowledge } \\
\quad \text { (6 items, alpha }=.46, \text { corrt }\end{array}$} \\
\hline $\begin{array}{l}\text { The only } 100 \% \text { sure way to avoid getting a sexually transmitted disease } \\
\text { (STD), or becoming pregnant, is to abstain (not have) from sexual activity. }\end{array}$ & .74 & 0.44 & .15 \\
\hline $\begin{array}{l}\text { There are many other ways of catching sexually transmitted diseases (STDs) } \\
\text { other than sexual intercourse. }\end{array}$ & 62 & 0.48 & .08 \\
\hline $\begin{array}{l}\text { Sexually transmitted diseases (STDs) that are caused by a virus, like Herpes or } \\
\text { HPV (Human Papillomavirus), can be completely cured. }\end{array}$ & .50 & 0.50 & .33 \\
\hline $\begin{array}{l}\text { It is not possible to get a sexually transmitted disease (STD) like Gonorrhea or } \\
\text { Syphilis from oral sex. }\end{array}$ & .54 & 0.50 & .28 \\
\hline It is easy to tell if you have an STD. & .69 & 0.46 & .34 \\
\hline $\begin{array}{l}\text { A sexually transmitted disease (STD) can be quickly diagnosed and treated } \\
\text { before any serious damage happens. }\end{array}$ & .24 & 0.43 & .20 \\
\hline \multicolumn{4}{|c|}{ Family Communication (5 items, alpha $=.69 ;$ desirable $=2$, not sure $=1$, undesirable $=0$ ) } \\
\hline $\begin{array}{l}\text { I go to a family member, or a trusted adult, with concerns or questions about } \\
\text { sex. }\end{array}$ & 1.24 & 0.92 & .55 \\
\hline $\begin{array}{l}\text { I go to a family member, or a trusted adult, with concerns or questions about } \\
\text { drugs or alcohol }\end{array}$ & 1.36 & 0.91 & .53 \\
\hline $\begin{array}{l}\text { A family member, or a trusted adult, helps me make healthy choices when it } \\
\text { comes to sexual decisions }\end{array}$ & 1.48 & 0.82 & .45 \\
\hline $\begin{array}{l}\text { I go to a family member, or trusted adult, when I need help or when I am in } \\
\text { trouble. }\end{array}$ & 1.68 & 0.70 & .34 \\
\hline I have talked about abstinence (not having sex) with family or a trusted adult. & 1.08 & 0.96 & .35 \\
\hline \multicolumn{4}{|l|}{$\begin{array}{l}\text { Attitude Toward Abstinence } \\
\qquad(3 \text { items, alpha }=.24 ; \text { desirable }=2, \text { not sure }=1 \text {, undesirable }=0)\end{array}$} \\
\hline It is not a good idea for teenagers to have sex. & 1.12 & 0.83 & .11 \\
\hline Having sex is the only way to show true love. & 1.77 & 0.59 & .12 \\
\hline Having sexual intercourse can cause a lot of stress for people my age. & 1.35 & 0.79 & .15 \\
\hline \multicolumn{4}{|l|}{$\begin{array}{l}\text { Behavioral Intent } \\
\quad(8 \text { items, alpha }=.61 ; \text { desirable }=2, \text { not sure }=1, \text { undesirable }=0)\end{array}$} \\
\hline I plan to be sexually abstinent (not have sex) until marriage. & 0.96 & 0.81 & .28 \\
\hline If someone were to pressure me to have sex, I could say no. & 1.60 & 0.71 & .25 \\
\hline $\begin{array}{l}\text { I plan to avoid drug and alcohol use because they increase my chances of } \\
\text { becoming pregnant or getting someone pregnant. }\end{array}$ & 1.45 & 0.78 & .41 \\
\hline $\begin{array}{l}\text { If someone who I liked wanted to have sex with me, drinking or using drugs } \\
\text { would make it more difficult to say no. }\end{array}$ & 0.99 & 0.91 & .11 \\
\hline I plan to avoid drinking alcohol until I turn 21 years old. & 1.35 & 0.85 & .32 \\
\hline I plan to avoid illegal drugs. & 1.81 & 0.53 & .45 \\
\hline If a friend asked me to take drugs I would say no. & 1.86 & 0.43 & .39 \\
\hline I am not going to smoke marijuana because it could lead to taking other drugs. & 1.67 & 0.68 & .46 \\
\hline
\end{tabular}

